\title{
Eupatorieae (Asteraceae) no Parque Estadual da Serra Dourada, Goiás, Brasil
}

\author{
Eupatorieae (Asteraceae) in Serra Dourada State Park, Goiás, Brazil
}

\author{
Rogério Neves Ribeiro ${ }^{1,2}$ \& Aristônio Magalhães Teles ${ }^{1}$
}

\begin{abstract}
Resumo
O Parque Estadual da Serra Dourada - PESD é o segundo maior Parque do estado de Goiás, abrangendo 30.000 hectares. Com o objetivo de contribuir com um melhor conhecimento sobre a diversidade de Asteraceae no estado de Goiás realizou-se o tratamento taxonômico da tribo Eupatorieae neste Parque. Eupatorieae está representada no PESD por 12 gêneros e 23 espécies. Chromolaena e Mikania foram os gêneros mais ricos em espécies sendo representados por cinco, seguido de Praxelis com três, Stomatanthes por duas e Ageratum, Ayapana, Barrosoa, Campuloclinium, Lomatozona, Pseudobrickellia, Stevia e Trichogonia por uma espécie, cada. Três espécies são reportadas pela primeira vez para Goiás: Campuloclinium chlorolepis, Stomatanthes loefgrenii e Barrosoa apiculata. Além disso, duas espécies constam na lista vermelha da flora do Brasil e são consideradas ameaçadas de extinção, Lomatozona artemissiifolia (em perigo) e S. loefgrenii (criticamente em perigo). É apresentada uma chave de identificação para os táxons, comentários taxonômicos, distribuição geográfica e ilustrações para as espécies.
\end{abstract}

Palavras-chave: Cerrado, compositae, florística, taxonomia.

\begin{abstract}
The Serra Dourada State Park - SDSP is the second largest Park in the Goiás state, covering 30,000 hectares. Aiming to understand the diversity of Asteraceae in Goiás we did the taxonomic treatment of Eupatorieae from this Park. The Eupatorieae is represented in SDSP by 12 genera and 23 species. Chromolaena and Mikania are the genera with the largest number of species represented by five, followed by Praxelis with three, Stomatanthes with two and Ageratum, Ayapana, Barrosoa, Campuloclinium, Lomatozona, Pseudobrickellia, Stevia and Trichogonia by one species each. Three species are reported for the first time for Goiás: Campuloclinium chlorolepis, Stomatanthes loefgrenii, and Barrosoa apiculata. Two species are listed in the Brazilian red list of threatened Flora, Lomatozona artemissiifolia (endangered) and $S$. loefgrenii (critically endangered). An identification key, taxonomic comments, geographical distribution, and illustrations for the species are provided.
\end{abstract}

Key words: Cerrado, compositae, floristic, taxonomy.

\section{Introdução}

Asteraceae é a maior família entre as Eudicotiledôneas com cerca de 1.600 gêneros e aproximadamente 25.000 espécies, agrupadas em 43 tribos, amplamente distribuídas no mundo, exceto na Antártida (Funk et al. 2009). A família é bastante representativa em hábitats temperados e tropicais montanos, secos e abertos (Judd et al. 2009). No Brasil, a família está representada por 2065 espécies, agrupadas em 278 gêneros e 28 tribos (Nakajima et al. 2015).
Eupatorieae compreende 2200 espécies reunidas em 182 gêneros (Hind \& Robinson 2007; Robinson et al. 2009), com distribuição no hemisfério ocidental e alguns gêneros pantropicais (Funk et al. 2009). No Brasil, Eupatorieae é a mais rica com 609 espécies distribuídas em 82 gêneros (Nakajima et al. 2015), sendo que em Goiás a tribo é representada por 119 espécies e 28 gêneros (Nakajima et al. 2015).

Dentre as tribos representadas no Brasil, Eupatorieae é reconhecida por suas espécies

\footnotetext{
${ }^{1}$ Universidade Federal de Goiás, Inst. Ciências Biológicas, Depto. Botânica, Campus Samambaia, saída para Nerópolis km 13, 74001-970, Goiânia, GO, Brasil

${ }^{2}$ Autor para Correspondência: silvero91@hotmail.com
} 
apresentarem comumente o hábito herbáceo ou arbustivo, ereto ou lianescente, folhas geralmente opostas, capítulos discoides, flores com corola branca ou lilás, estiletes longos e com ápice comumente clavado, e apêndices frequentemente coloridos (Bremer 1994).

O primeiro estudo com as espécies de Eupatorieae ocorrentes no Brasil foi feito por Baker (1876), que a considerou como uma subfamília - Eupatoriaceae [sic], e a dividiu em três tribos: Adenostyleae Baker, Agerateae Baker e Piquerieae Baker. Após este trabalho, poucos estudos foram realizados com espécies ou gêneros de Eupatorieae do Brasil, podendose destacar Barroso (1950, 1958), Matzenbacher (1979), Esteves (2001), Ritter \& Miotto (2005), Ferreira (2010), Roque et al. (2012), Hattori (2013) e Fernandes (2014).

Apesar de Asteraceae ser bem representada em Goiás, ainda há uma grande lacuna de conhecimento acerca das espécies ocorrentes no estado e de sua distribuição, devido a poucos trabalhos florísticos. Até o momento, a flora de Asteraceae do estado é conhecida somente por dois trabalhos para a família que são os de Bringel Jr. \& Cavalcanti (2009) e Moreira \& Teles (2014).

Portanto, há uma grande lacuna sobre o conhecimento da diversidade de Asteraceae na flora de Goiás, com uma enorme carência de bibliografias que favoreçam a identificação dos táxons ocorrentes no estado. Diante deste cenário, o presente estudo tem por objetivo apresentar o tratamento taxonômico das espécies da tribo Eupatorieae ocorrentes no Parque Estadual da Serra Dourada, Goiás, Brasil.

\section{Material e Métodos}

O Parque Estadual da Serra Dourada PESD (Fig. 1) localiza-se entre as coordenadas $16^{\circ} 06^{\prime} 02^{\prime \prime}-16^{\circ} 03^{\prime} 52^{\prime \prime} \mathrm{S}$ e $50^{\circ} 10^{\prime} 59^{\prime \prime}-50^{\circ} 10^{\prime} 12^{\prime \prime}$ W, com altitude que varia de 726 a 1080 m.s.m. (Barbosa 2008) e abrange uma área de aproximadamente 30.000 hectares, sendo considerado o segundo maior Parque estadual de Goiás. O PESD abrange algumas fitofisionomias do bioma Cerrado, tais como a floresta semidecídua, floresta de galeria, buritizal, campo limpo, cerrado sentido restrito e cerrado rupestre (Moreira \& Teles 2014).

Coletas mensais foram realizadas de setembro de 2011 a setembro de 2012 através do método de caminhamento (Filgueiras et al. 1994). Todo material coletado foi processado segundo as técnicas usuais em taxonomia vegetal (Mori et al. 2011) e incorporado ao acervo do herbário da Universidade Federal de Goiás (herbário UFG). Além do material coletado também foram examinados materiais previamente coletados na área de estudo, e que se encontram incluídos no herbário da UFG.

A terminologia morfológica adotada foi baseada em Roque \& Bautista (2008), Gonçalves \& Lorenzi (2011) e Beentje (2012). A circunscrição dos gêneros foi baseada em King \& Robinson (1987). Optou-se por descrições morfológicas diagnósticas, portanto, para a confecção da chave de identificação foram utilizadas características presentes nas descrições dos táxons e características observadas nas plantas, porém que não necessariamente constam nas descrições. Os dados sobre o risco de extinção das espécies foi baseado em Nakajima et al. (2013).

\section{Resultados e Discussão}

Eupatorieae Cass., J. Phys. Chim. Hist. Nat. Arts 88: 202. 1819.

Subarbustos, arbustos ou trepadeiras volúveis. Folhas opostas, às vezes totalmente alternas ou raramente alternas com opostas, margem inteiras, crenadas, serrilhada, serreadas, denteadas, pinatissectas, pinatífidas, sésseis ou pecioladas. Capitulescência corimbiforme, paniculiforme, dicasiforme ou racemoespiciforme. Capítulos homógamos, discoides, sésseis ou pedunculados. Invólucros imbricados ou eximbricados, campanulado, cilíndrico ou turbinado, brácteas involucrais 1-multisseriadas, geralmente persistentes, raramente caducas. Eixo da inflorescência, plano, convexo ou cônico, epaleáceo ou paleáceo, glabro. Flores 4-70, brancas, lilases ou creme a esverdeada. Cipselas obcônicas, prismáticas, cilíndricas, raramente achatadas, 3-6-costadas. Pápus 1-seriado, constituído geralmente de cerdas e raramente de páleas, aristas ou ausente.

Eupatorieae está representada no PESD por 12 gêneros e 23 espécies. Chromolaena DC. e Mikania Willd. foram os gêneros com maiores números de espécies representadas por cinco cada, seguido de Praxelis Cass. com três, Stomatanthes R.M. King \& H. Rob. por duas e Ageratum L., Ayapana Spach, Barrosoa 


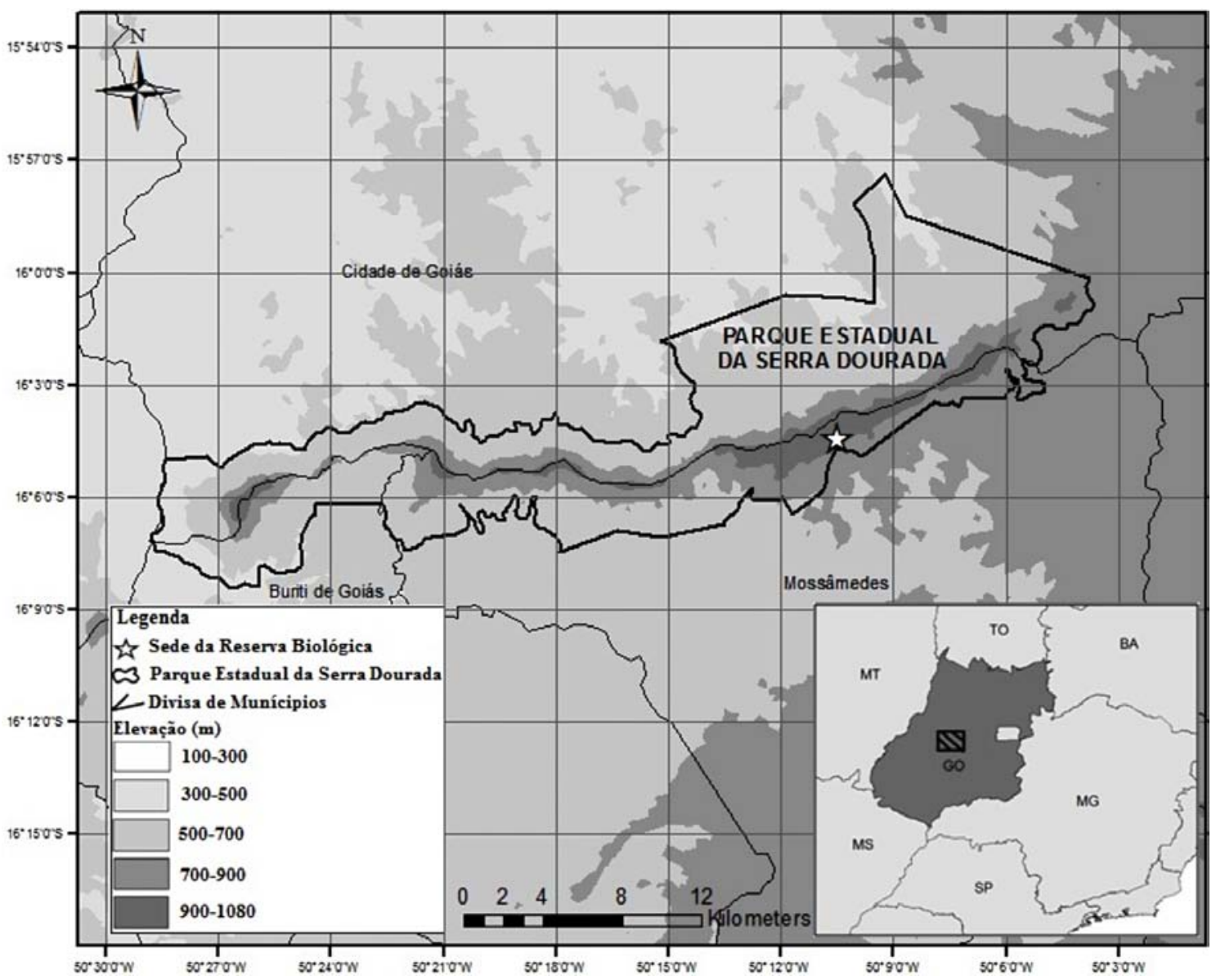

Figura 1 - Localização do Parque Estadual da Serra Dourada, Goiás, Brasil. Figure 1 - Location of Serra Dourada State Park, Goiás, Brazil.

R.M. King \& H. Rob., Campuloclinium DC., Lomatozona Baker, Pseudobrickellia R.M. King \& H. Rob., Stevia Cav. e Trichogonia Gardner com uma espécie cada. Três espécies são reportadas pela primeira vez para Goiás: Barrosoa apiculata (Gardner) R.M. King \& H. Rob., Campuloclinium chlorolepis (Baker) R.M. King \& H. Rob. e Stomatanthes loefgrenii (B.L. Rob.) H. Rob.

\section{Chave para as espécies de Eupatorieae ocorrentes no PESD, Goiás, Brasil}

1. Invólucro eximbricado, ou seja, com brácteas involucrais de tamanhos semelhantes que se abrem na maturidade (Figs. 2b,d,f,i e 4m).

2. Lâmina foliar oblanceolada; brácteas involucrais 5-seriadas (Fig. 2d)

2. Ayapana amygdalina

2'. Lâmina foliar ovada, deltoide, elíptica ou lanceolada; brácteas involucrais 1-3-seriadas.

3. Brácteas involucrais 1-seriada (Fig. 4m).

4. Cinco brácteas e cinco flores por capítulo; pápus aristado, aristas planas na base (Fig. 4n) 20. Stevia heptachaeta

4'. Quatro brácteas e quatro flores por capítulo; pápus cerdoso, cerdas cilíndricas.

5. Subarbustos eretos; lâmina foliar com base truncada (Fig. 4c)

13. Mikania officinalis

5’. Trepadeiras volúveis; lâmina foliar com base arredondada, aguda ou cordada 
6. Lâmina foliar com base arredondada ou aguda (Fig. 4c-d).

7. Lâmina foliar com margem inteira (Fig. 4d); lóbulos da corola adaxialmente pilosos (Fig. 4e) 14. Mikania pohliana

7'. Lâmina foliar com margem serreada; lóbulos da corola adaxialmente papilosos (Fig. 4f-g). 15. Mikania psilostachya

6’. Lâmina foliar com base cordada (Fig. 4a-b).

8. Lâmina foliar com margem crenada (Fig. 4b); invólucro $3 \times 1$ mm.

12. Mikania microcephala

8'. Lâmina foliar com margem inteira a esparsamente denteada (Fig. 4a); invólucro $6 \times 2$ $\mathrm{mm}$. 11. Mikania cordifolia

3'. Brácteas involucrais 2-3-seriadas.

9. Pápus paleáceo, 5-aristado (Fig. 2c)

1. Ageratum conyzoides

9'. Pápus cerdoso ou ausente.

10. Folhas alternas (Fig. 5c), ou opostas e alternas na mesma planta (Fig.5a).

11. Lâmina foliar ovada; invólucro cilíndrico; flores 6-7 por capítulo, corola glabra externamente; pápus cerdoso.

12. Arbustos; folhas alternas na base, opostas próximo ao ápice (Fig.5a)....

21. Stomatanthes dyctiophyllus

12'. Subarbustos; folhas todas alternas (Fig. 5c)

22. Stomatanthes loefgrenii

11'. Lâmina foliar lanceolada; invólucro campanulado; flores 50-70 por capítulo, corola completamente pilosa externamente; pápus ausente.

23. Trichogonia cinerea

10’. Folhas todas opostas.

13. Capítulos $8-10 \times 6 \mathrm{~mm}$; brácteas involucrais pubescentes; eixo da inflorescência cônico

4. Campuloclinium chlorolepis

13'. Capítulos 3-4 × 3-4 mm; brácteas involucrais glandulosas; eixo da inflorescência convexo

3. Barrosoa apiculata

1'. Invólucro imbricado, ou seja, com brácteas involucrais fortemente sobrepostas e de tamanhos gradualmente maiores (Fig. 3b).

14. Lâmina foliar com margem lirado-pinatissecta (Fig. 3i); pápus coroniforme-aristado (Fig. 4j) ....

10. Lomatozona artemissiifolia

14’. Lâmina foliar com margem inteira, serreada, crenada ou denteada; pápus cerdoso.

15. Folhas congestas (Fig. 4l); lâmina foliar linear . 19. Pseudobrickellia brasiliensis

15'. Folhas espaçadas; lâmina foliar lanceolada, oblonga, ovada, elíptica ou filiforme.

16. Eixo da inflorescência cônico (Fig. 4k); brácteas involucrais caducas.

17. Folhas verticiladas (Fig. 4h); lâmina foliar filiforme 16. Praxelis capillaris

17’. Folhas opostas (Fig. 4i-j); lâmina foliar oblonga ou ovada.

18. Folhas sésseis, lâmina foliar oblonga (Fig. 4j); capítulo com 47-70 flores... 18. Praxelis grandiflora

18'. Folhas pecioladas, lâmina foliar ovada (Fig. 5i); capítulo com 30-40 flores . 17. Praxelis diffusa

16'. Eixo da inflorescência plano a convexo; brácteas involucrais persistentes.

19. Folhas alternas (Fig. 3h); capítulos com 3-4 flores

9. Chromolaena stachyophylla

19’. Folhas opostas (Fig. 3a,c); capítulos com mais de 19 flores.

20. Capitulescência corimbiforme.

21. Arbustos eretos; eixo da inflorescência plano.

22. Lâmina foliar lanceolada, margem serreada (Fig. 3a); invólucro cilíndrico.

5. Chromolaena laevigata

22’. Lâmina foliar ovada, margem crenada; invólucro turbinado (Fig. 3b).

6. Chromolaena horminoides

21'. Arbustos apoiantes; eixo da inflorescência convexo.....

7. Chromolaena maximilianii

20’. Capitulescência dicasiforme 8. Chromolaena squalida 
1. Ageratum conyzoides L. Sp. Pl. 2: 839.1753. Fig. 2a-c.

Subarbustos eretos, $20 \mathrm{~cm}$ alt. Folhas opostas, lâmina ovada, $0,5-4 \times 0,3-2,5 \mathrm{~cm}$, ápice agudo, base cordada a arredondada, margem crenada a denteada, serícia adaxialmente, serícia e glandulosa abaxialmente, pecíolo 5-12 mm compr. Capitulescência corimbiforme. Capítulos com pedúnculos 2-10 $\mathrm{mm}$ compr., pilosos. Invólucro eximbricado, campanulado, $2-4 \times 2-3 \mathrm{~mm}$, brácteas involucrais 2-3-seriadas, glabras. Eixo da inflorescência cônico, epaleáceo. Flores 35-40 por capítulo, corola lilás, lóbulos adaxialmente pilosos, abaxialmente glabros. Cipselas prismáticas, 2 mm compr., 5-costadas, pilosas. Pápus paleáceo, 5-aristado, páleas livres, achatadas na base.

Material examinado: Reserva Biológica Prof. José Ângelo Rizzo, em volta do alojamento, 25.IV.2009, A.M. Teles et al. 575 (UFG).

Espécie com distribuição pantropical (Carneiro \& Irgang 2005). No Brasil ocorre nos estados da Bahia, Goiás, Minas Gerais, Paraíba, Pernambuco e Rio de Janeiro (Hind \& Miranda 2008; Nakajima 2015). Caracteriza-se pelo pápus paleáceo, formado por cinco aristas achatadas na base. Na área de estudo a espécie foi coletada em ambiente antropizado.

2. Ayapana amygdalina (Lam.) R.M. King \& H. Rob. Phytologia 20(3): 211. $1970 . \quad$ Fig. 2d

Subarbustos eretos, ca. $40 \mathrm{~cm}$ alt. Folhas opostas, lâmina oblanceolada, 1,5-8 × 0,5-2 $\mathrm{cm}$, ápice arredondado, base aguda, margem esparsamente serreada, pubescente e glandulosas em ambas as faces, sésseis. Capitulescência corimbiforme. Capítulos com pedúnculos 2-5 mm compr., pubescentes. Invólucro eximbricado, campanulado, $5 \times 4 \mathrm{~mm}$, brácteas involucrais 5-seriadas, pilosas e glandulosas. Eixo da inflorescência plano, epaleáceo. Flores 20-40 por capítulo, corola lilás, lóbulos papilosos adaxialmente e abaxialmente glabros. Cipselas prismáticas, $1 \mathrm{~mm}$ compr., 5-costadas, glabras. Pápus cerdoso, cerdas livres, cilíndricas.

Material examinado: Serra Dourada, 08.IX.1976, P. Gibbs et al. 2753 (UFG); da Reserva Biológica até os córregos Cafundó e Piçarrão, 19.VII.1994, J.A. Rizzo et al. 11564 (UFG); próximo da pista de Asa Delta, 30.VII.2011, R.S. Guida et al. 27 (UFG).

Distribuída na América Central e América do Sul (King \& Robinson 1987). No Brasil ocorre em quase todas as regiões geográficas, exceto na região Sul (Hattori 2015). Caracterizada pelas folhas com lâmina oblanceolada e brácteas involucrais lilás. No PESD ocorre em borda de floresta semidecídua, em cerrado rupestre e em área de cerrado sentido restrito.

3. Barrosoa apiculata (Gardner) R.M. King \& H. Rob., Phytologia 24(3): 184. $1972 . \quad$ Fig. 2e-g Arbustos eretos, ca. 1,5 m alt. Folhas opostas, lâmina ovada a deltoide, $2-11 \times 1-5,5 \mathrm{~cm}$, ápice agudo, base arredondada, margem serreada, glandulosa em ambas as faces. Pecíolo 0,5-3 cm compr. Capitulescência paniculiforme. Capítulos com pedúnculos $3-5 \mathrm{~mm}$ compr., seríceos. Invólucro eximbricado, campanulado 3-4 × 3-4 $\mathrm{mm}$, brácteas involucrais 2-seriadas, glandulosas. Eixo da inflorescência convexo, epaleaceo. Flores 33-35 por capítulo, corola lilás, lóbulos adaxialmente papilosos, abaxialmente glabros. Cipselas prismáticas, 6-costadas, 1,5 mm compr., pilosas. Pápus cerdoso, cerdas livres, cilíndricas.

Material examinado: Subida de acesso à Reserva Biológica Prof. José Ângelo Rizzo, 25.III.2011, A.M. Teles et al. 1231 (UFG).

Ocorre nos estados de Minas Gerais, São Paulo, Rio de Janeiro (Ferreira 2015a) e aqui reportada pela primeira vez para o estado de Goiás. Barrosoa apiculata se distingue das demais espécies da área de estudo por apresentar invólucro eximbricado, 2-seriado e eixo da inflorescência convexo. No PESD ocorre em borda de floresta semidecídua.

4. Campuloclinium chlorolepis (Baker) R.M. King \& H. Rob., Phytologia 24: 171. $1972 . \quad$ Fig. 2h-i

Subarbustos eretos, $70-90 \mathrm{~cm}$ alt. Folhas opostas, lâmina ovada, $1,5-4,5 \times 1-2,5 \mathrm{~cm}$, ápice agudo, base cuneada, margem serreada, escabra e glandulosa em ambas as faces. Pecíolo 2-5 mm compr. Capitulescência paniculiforme. Capítulos com pedúnculos 5-20 mm compr., pilosos. Invólucro eximbricado, campanulado $8-10 \times 6 \mathrm{~mm}$, brácteas involucrais 3 -seriadas, pubescentes. Eixo da inflorescência cônico, epaleáceo. Flores 32-40 por capítulo, corola lilás, lóbulos adaxialmente papilosos, abaxialmente glabros. Cipselas prismáticas 5-costadas, $5 \mathrm{~mm}$ compr., papilosas e pilosas. Pápus cerdoso, cerdas livres, cilíndricas.

Material examinado: Cabeceira do rio Índio Grande, 15.IV.1994, J.A. Rizzo et al. 11287 (UFG); subida de acesso à Reserva Biológica Prof. Dr. José Ângelo Rizzo, 29.IV.2011, G.H. Silva \& A.M. Teles 3 (UFG); 27.V.2011, A.M. Teles et al. 1291 (UFG). 


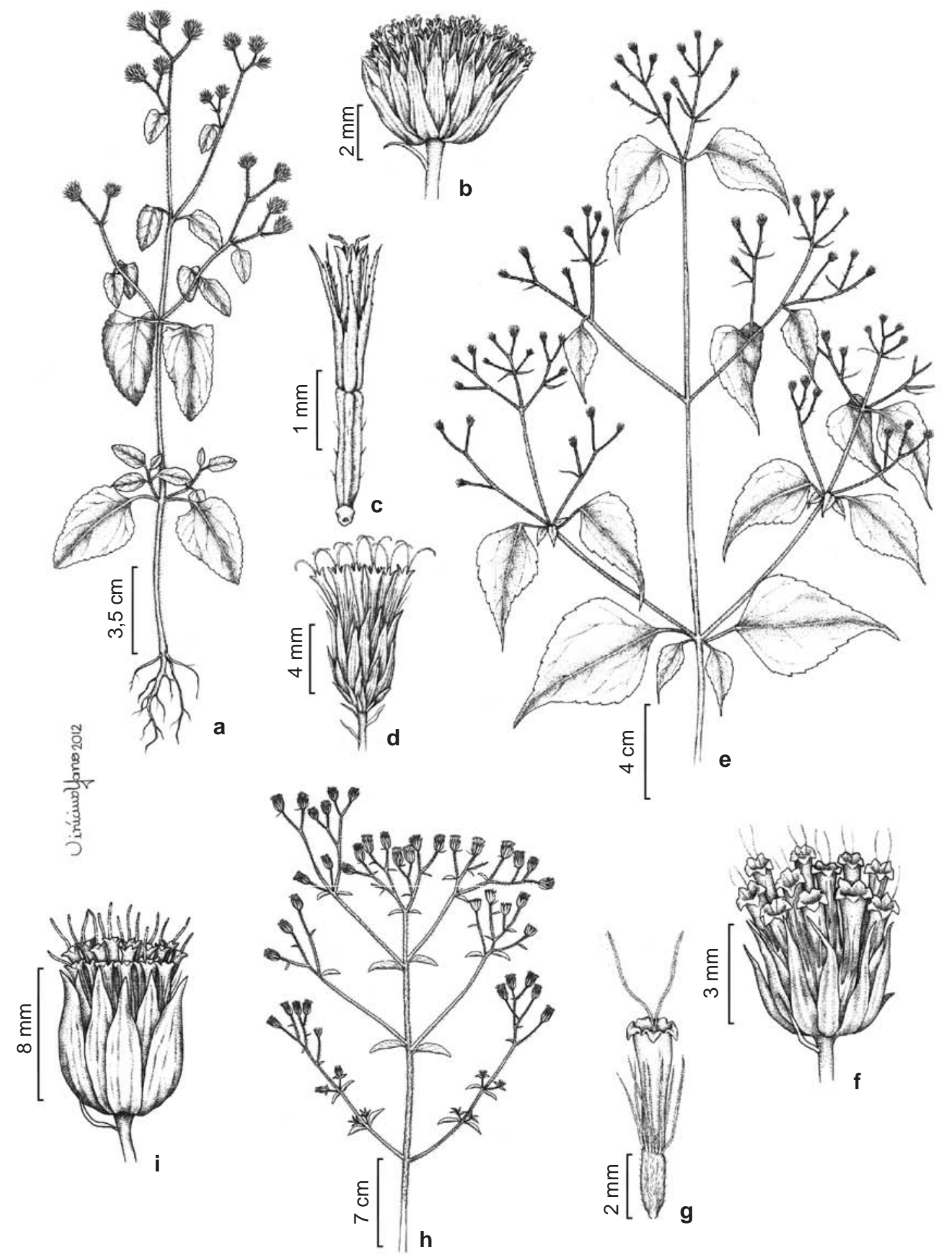

Figura 2 - a-c. Ageratum conyzoides - a. hábito; b. capítulo; c. flor (Teles et al. 575). d. Ayapana amygdalina - d. capítulo (Guida 27). e-g. Barrosoa apiculata - e. ramo florido; f. capítulo; g. flor (Teles et al. 1231). h-i. Campuloclinium chlorolepis - h. ramo florido; i. capítulo (Teles et al. 1291).

Figure 2 - a-c. Ageratum conyzoides - a. habit; b. capitula; c. floret (Teles et al. 575). d. Ayapana amygdalina - d. capitula (Guida 27). e-g. Barrosoa apiculata - e. flowering branch; f. capitula; g. floret (Teles et al. 1231). h-i. Campuloclinium chlorolepis - h. flowering branch; i. capitula (Teles et al. 1291). 
Ocorre nos estados de Minas Gerais, Paraná, São Paulo (Ferreira 2015b) e aqui reportada pela primeira vez para o estado de Goiás. Campuloclinium chlorolepis é reconhecida por apresentar capítulos grandes $(8-10 \times 6 \mathrm{~mm})$. No PESD ocorre em borda de floresta de galeria.

5. Chromolaena laevigata (Lam.) R.M. King \& H. Rob., Phytologia 20(3): 202. $1970 . \quad$ Fig. 3a

Arbustos eretos, $2 \mathrm{~m}$ alt. Folhas opostas, lâmina lanceolada $0,5-10 \times 0,2-2,5 \mathrm{~cm}$, ápice agudo, base aguda, margem serreada, glabra e vernicosa em ambas as faces. Pecíolo $1-5 \mathrm{~mm}$ compr. Capitulescência corimbiforme. Capítulos com pedúnculos 4-10 mm compr., glabros. Invólucro imbricado, cilíndrico, 8-10 × 3-4 mm, brácteas involucrais 7 -seriadas, glabras. Eixo da inflorescência plano, epaleáceo. Flores 20-21 por capítulo, corola lilás, lóbulos glabros em ambas as faces. Cipselas obcônicas, 5-costadas, 4 mm compr., pilosas nas costelas. Pápus cerdoso, cerdas livres, cilíndricas.

Material examinado: Entre a trilha da rampa de decolagem de asa deltas e o alojamento, 25.IV.2009, A.M. Teles et al. 567 (UFG).

Ocorre na América do Sul e América Central (King \& Robinson 1987), sendo distribuída amplamente no Brasil (Oliveira 2015a). Chromolaena laevigata se diferencia das demais espécies congenéricas pelas folhas glabras e vernicosas. Coletada no PESD em áreas de cerrado rupestre.

6. Chromolaena horminoides DC., Prodr. 5: 133. 1836.

Fig. 3b

Arbustos eretos, 1-1,1 m alt. Folhas opostas, lâmina ovada, $0,5-6 \times 0,2-2,5 \mathrm{~cm}$, ápice agudo, base obtuso, margem crenada, hirsuto e glandulosa em ambas as faces, pecíolo $1-3 \mathrm{~mm}$ de compr., hirsuto. Capitulescência corimbiforme. Capítulos com pedúnculos 3-10 $\mathrm{mm}$ compr., hirsuto e glanduloso. Invólucro imbricado, turbinado 5-15 $\times 3-5 \mathrm{~mm}$, brácteas involucrais 7-8-seriadas, glabras. Eixo da inflorescência plano, paleáceo, pálea $1 \times 0,5 \mathrm{~mm}$, lanceolada. Flores 25-30 por capítulo, corola lilás, lóbulos glandulosos adaxialmente, glabros abaxialmente. Cipselas cilíndrica 5-costadas, $3 \mathrm{~mm}$ compr., pilosas nas costelas. Pápus cerdoso, cerdas livres, cilíndricas. Material examinado: Área da UFG, 1.VI.1969 J.A. Rizzo 4262 (UFG); entre o alojamento e a rampa, 29.IV.2009, A.M. Teles \& T.H.S. Sampaio 599 (UFG); próximo ao Areial 14.VI.2010, A.M. Teles et al. 883
(UFG); próximo a nascente, 27.V.2011, G.H. Silva et al. 35 (UFG).

Ocorre nos estados da Bahia, Goiás, Mato Grosso do Sul, Mato Grosso, Minas Gerais, São Paulo e no Distrito Federal (Oliveira 2015a). Caracterizada por apresentar involucro turbinado com brácteas involucrais alvacentas. A espécie foi coletada no PESD em cerrado rupestre e em borda de mata de galeria

7. Chromolaena maximilianii (Schrad. ex DC.) R.M. King \& H. Rob., Phytologia 49(1): 4. 1981.

Fig. 3c

Arbustos apoiantes, 0,9-2,5 m alt. Folhas opostas, lâmina ovada, $1-9 \times 0,3-4,5 \mathrm{~cm}$, ápice agudo, base atenuada a arredondada, margem denteada, escabra em ambas as faces. Pecíolo 3-8 mm compr. Capitulescência corimbiforme. Capítulos com pedúnculos 13-30 mm compr., pubescente. Invólucro imbricado, cilíndrico, 6-1 $1 \times$ 3-5 mm, brácteas involucrais 4-5-seriado, glabros. Eixo da inflorescência convexo, paleáceo, pálea $3 \times$ $0,3 \mathrm{~mm}$, oblanceolada. Flores $35-48$ por capítulo, corola alvacentas, lóbulos com ambas as faces glabros. Cipselas prismáticas, 3-costadas, pilosas. Pápus cerdoso, cerdas livres, cilíndricas.

Material examinado: Borda da mata galeria da nascente que abastece o alojamento 29.V.2009, A.M. Teles \& T.H.S. Sampaio 590 (UFG); 29.IV.2011, G.H. Silva \& A.M. Teles 1 (UFG); fazenda Quinta da Serra, 27.IV.2012, R.S. Guida et al. 44 (UFG).

Ocorre na Argentina, Cuba, Guianas e México (Barroso 1950), amplamente distribuída no Brasil (King \& Robinson 1987; Oliveira 2015a), encontrada em áreas degradadas, restinga e bordas de florestas (Esteves 2001). Diferencia-se das demais espécies do gênero ocorrentes na área por ser a única com hábito de crescimento apoiante. No PESD ocorre em borda de floresta de galeria.

8. Chromolaena squalida (DC.) R.M. King \& H. Rob., Phytologia 20: 206. $1970 . \quad$ Fig. 3d-g Arbustos a subarbustos eretos, $0,6-1,5 \mathrm{~m}$ alt. Folhas opostas, lâmina ovada a oblonga-elíptica, $0,5-6 \times 0,2-2,5 \mathrm{~cm}$, ápice agudo, base aguda a cuneada, margem serreada, esparsamente crenada, escabra, pubescente, estrigosa e glandulosa abaxialmente, escabra, pilosa, estrigosa e glandulosa adaxialmente. Pecíolo 0,2-1,2 cm compr. Capitulescência dicasiforme. Capítulos com pedúnculos 1-15 mm compr., escabros, pilosos e glandulosos. Invólucro imbricado, cilíndrico ou campanulado 2-10 × 2-5 mm, brácteas involucrais 
6-7-seriadas, glabras ou pubescentes. Eixo da inflorescência plano ou convexo, epaleáceo. Flores 20-30 por capítulo, corola alvacenta a lilás, lóbulos adaxialmente papilosos e abaxialmente glabros. Cipselas prismática, fusiformes 4-6-costadas, 3-4 mm compr., pilosas. Pápus cerdoso, cerdas livres, cilíndricas.

Material selecionado: Cabeceira do rio Índio Grande, 18.III.1994, J.A. Rizzo et al. 11169 (UFG); entre a porteira e a guarita de vigilância, 24.IV.2009, A.M. Teles et al. 558 (UFG); Reserva Biológica Prof. Dr. José Ângelo Rizzo, após o Areial, 29.I.2010, A.M. Teles \& T.H.S. Sampaio. 701 (UFG); afloramentos rupestres a cerca de $2 \mathrm{Km}$ após o Areial, 25.III.2011, A.M. Teles et al. 1255 (UFG); fazenda Quinta da Serra, 27.IV.2012, R.S. Guida et al. 47 (UFG); 27.IV.2012, R.S. Guida et al. 48 (UFG).

Ocorre na Bolívia, Brasil, Colômbia, Peru e Venezuela (King \& Robinson 1987; Esteves 2001). No Brasil ocorre nos estados da região Sul e Sudeste, além da Bahia, Goiás, Mato Grosso, Pará, Rondônia, Tocantins e no Distrito Federal (Oliveira 2015a). Distingue-se das demais espécies do gênero ocorrentes no PESD por apresentar capitulescência dicasiforme e lâmina foliar com nervuras proeminentes abaxialmente. Esta espécie é extremamente polimorfa e variável em relação ao formato da lâmina foliar sendo oval a oblongo-elíptica (Fig. 3d-g) e ao tipo de indumento. Segundo Esteves (2001), C. squalida é frequente em ambientes perturbados e bordas de florestas, ocorrendo algumas vezes como invasora de pastos e lavouras. No PESD é uma espécie comum, encontrada no cerrado sentido restrito, no cerrado rupestre e nas bordas de floresta de galeria.

9. Chromolaena stachyophylla (Spreng.) R.M. King \& H. Rob., Phytologia 20: 206. 1970.

Fig. 3h

Subarbustos eretos, 30-60 cm alt. Folhas alternas, lâmina lanceolada, 0,8-5,5 × 0,4- 1,5 $\mathrm{cm}$, ápice agudo, base aguda a cuneada, margem denteada, pilosa adaxialmente, pubescente e glandulosa abaxialmente. Pecíolo 1-6 mm compr. Capitulescência corimbiforme. Capítulos com pedúnculos 2-7 $\mathrm{mm}$ compr. Invólucro imbricado, campanulado, 5-6 × 4-5 mm, brácteas involucrais 3-4-seriadas, pilosas na ápice. Eixo da inflorescência plano, paleáceo. Flores 3-4 por capítulo, corola lilás, lóbulos papilosos adaxialmente e glabros abaxialmente. Cipselas obdeltoides, 5-8-costadas, $3 \mathrm{~mm}$ compr., pilosas. Pápus cerdoso, cerdas livres, cilíndricas.
Material examinado: Da Reserva Biológica até os córregos Cafundó e Piçarrão, 16.VI.1994, J.A. Rizzo et al. 11437 (UFG); 18.VIII.1994, J.A. Rizzo et al. 11891 (UFG).

Ocorre no Brasil e na Bolívia (King \& Robinson 1987). No Brasil ocorre nos estados da Bahia, Goiás, Mato Grosso, Minas Gerais, Paraná, Piauí, São Paulo e no Distrito Federal (Oliveira 2015a). Distingue-se facilmente das demais espécies do gênero ocorrentes na área de estudo por apresentar folhas alternas e capítulos paucifloros (3-4 flores). No PESD ocorre em cerrado rupestre.

10. Lomatozona artemisiifolia Baker, Fl. Bras. 6(2): 199. 1876.

Fig. $4 \mathrm{i}-\mathrm{j}$

Ervas a subarbustos eretos, 30-60 cm alt. Folhas opostas, lâmina ovada, 3-3,7 × 0,5-1,5 cm, ápice agudo, base truncada, margem liradopinatissecta, glandulosa em ambas as faces. Pecíolo 0,3-1,5 cm compr. Capitulescência paniculiforme. Capítulos com pedúnculos 0,5-2,5 cm compr., glandulosos. Invólucro imbricado, campanulado, 1-5 × 2-5 mm, brácteas involucrais 5-6-seriadas, incanas. Eixo da inflorescência convexo, paleáceo, páleas $5 \times 0,3 \mathrm{~mm}$, oblanceoladas. Flores 27-32 por capítulo, corola lilás, lóbulos glabros em ambas as faces. Cipselas obcônicas, 5-costadas, 2,5 mm compr., escabras. Pápus coroniforme-aristado.

Material selecionado: Área da UFG, 01.VI.1969, J.A. Rizzo 4253 (UFG); 02.VII.1969, J.A. Rizzo 4328 (UFG); a 3 km do trevo de Mossâmedes para a cidade de Goiás, a esquerda da rodovia, 12.V.1994, J.A. Rizzo et al. 11305 (UFG); lado oposto da trilha que vai para o Morro do Mirante, 30.V.2009, A.M. Teles \& T.H.S. Sampaio 604 (UFG); próximo ao Areial, 14.VI.2010, A.M. Teles et al. 884 (UFG); próximo a pista de asa delta, 30.VII.2011, R.S. Guida, et al. 26 (UFG).

Endêmica de Goiás (King \& Robinson 1987; Oliveira 2015b). Caracteriza-se por apresentar lâmina foliar com margem lirado-pinatissecta e glandulosa em ambas as faces. Reportada como em perigo de extinção devido à distribuição restrita e aos poucos registros (Nakajima et al. 2013).

11. Mikania cordifolia (L. f.) Willd., Sp. Pl. 3(3): 1746. 1803.

Fig. $4 \mathrm{a}$

Trepadeiras volúveis. Folhas opostas, lâmina ovada, 3-8 × 1-6,5 cm, ápice agudo, base cordada, margem inteira a esparsamente denteada, estrigosa em ambas as faces. Pecíolo 5-47 mm compr. Capitulescência paniculiforme. Capítulos com pedúnculos 2-5 mm compr., pilosos. Invólucro eximbricado, cilíndrico, $6 \times$ 

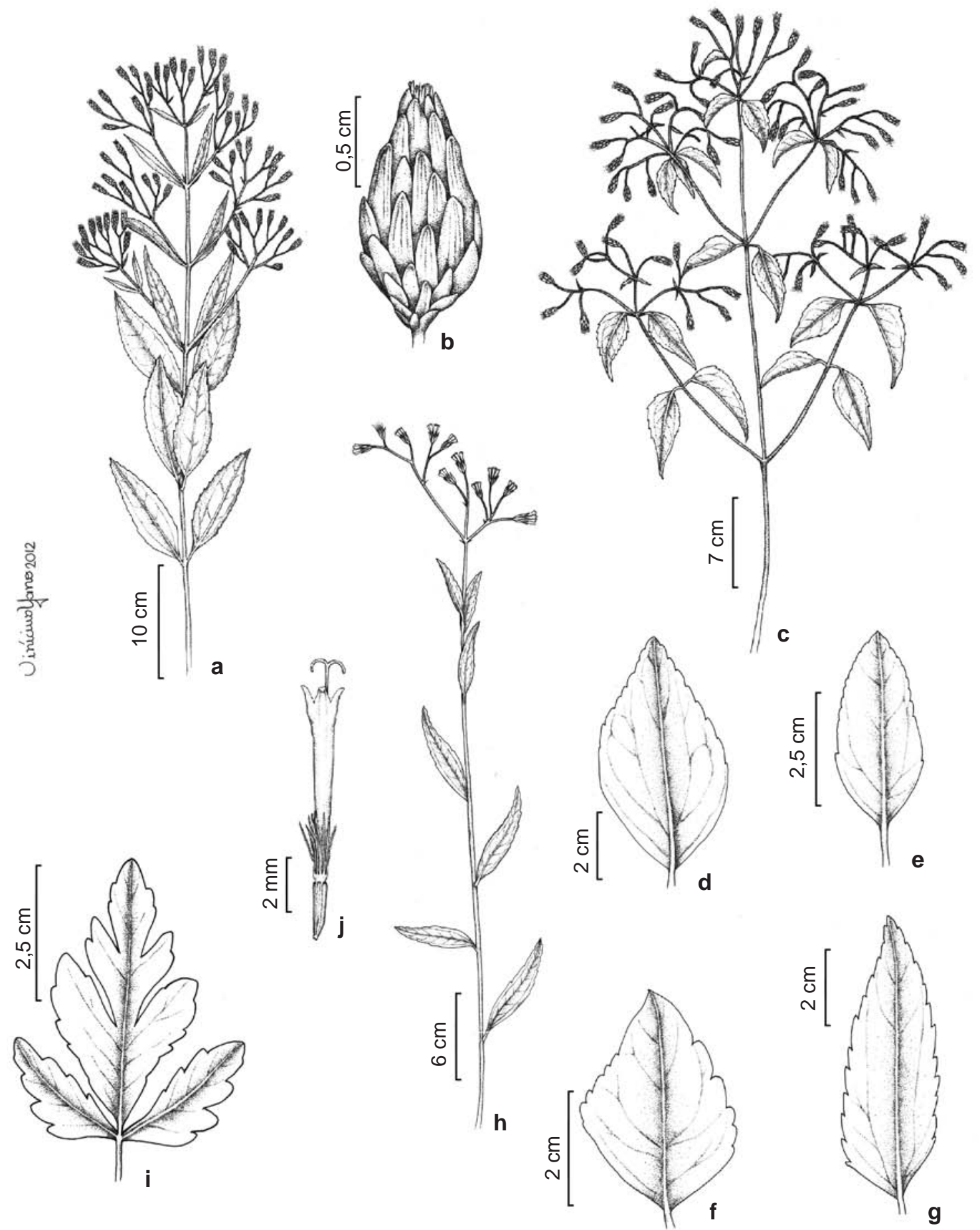

Figura 3 - a. Chromolaena laevigata - a. ramo florido (Teles et al. 567). b. Chromolaena horminoides - b. capítulo (Teles et al. 883). c. Chromolaena maximilianii - c. ramo florido (Teles \& Sampaio 590). d-g. Chromolaena squalida - d-g. variação de lâmina foliar (d. Teles et al. 1220; e. Rizzo et al. 22944; f. Teles et al. 1225; g. Guida et al. 47). h. Chromolaena stachyophylla - h. ramo florido (Rizzo et al. 11891). i-j. Lomatozona artemisiifolia - i. folha; j. flor (Guida et al. 26).

Figure 3 - a. Chromolaena laevigata - a. flowering branch (Teles et al. 567). b. Chromolaena horminoides - b. capitula (Teles et al. 883). c. Chromolaena maximilianii - c. flowering branch (Teles \& Sampaio 590). d-g. Chromolaena squalida - d-g. leaf-blade variation (d. Teles et al. 1220; e. Rizzo et al. 22944; f. Teles et al. 1225; g. Guida et al. 47). h. Chromolaena stachyophylla - h. flowering branch (Rizzo et al. 11891). i-j. Lomatozona artemisiifolia - i. leaf; j. floret (Guida et al. 26). 
$2 \mathrm{~mm}$, brácteas involucrais 1-seriada, pilosas. Eixo da inflorescência plano, epaleaceo. Flores 4 por capítulo, corola branca, lóbulo adaxialmente papiloso e abaxialmente papiloso. Cipselas cilíndricas, 5-costadas, 3mm compr., glabras. Pápus cerdoso, cerdas livres, cilíndricas.

Material examinado: Fazenda Quinta da Serra seguindo a trilha após a mata do $2^{\circ}$ riacho, 29.VIII.2012, G.H. Silva 89 (UFG).

Ocorrente no Sudeste dos Estados Unidos, México, América Central, Índias Ocidentais e América do Sul (King \& Robinson 1987), sendo comum no Brasil (Ritter \& Miotto 2005). Assemelha-se a $M$. microcephala, entretanto esta última possui capitulescência paniculiforme e invólucro campanulado. No PESD ocorre em borda de floresta de galeria.

12. Mikania microcephala DC., Prodr. 5: 200.1836.

Fig. 4b

Trepadeiras volúveis. Folhas opostas, lâmina ovada, $0,5-4,5 \times 0,5-3,5 \mathrm{~cm}$, ápice agudo, base cordada, margem crenada, adaxialmente estrigosa, abaxialmente pilosa. Pecíolo 0,3-3,5 mm compr. Capitulescência paniculiforme. Capítulos com pedúnculos 0,1-0,3 mm compr., pilosos. Invólucro eximbricado, campanulado, 3 $\times 1 \mathrm{~mm}$, brácteas involucrais 1-seriada, seríceas. Eixo da inflorescência plano, epaleáceo. Flores 4 por capítulos, corola branca, lóbulos adaxialmente papiloso, abaxialmente glabro. Cipselas cilíndricas, 5-costadas, 1 mm compr., papilosas. Pápus cerdoso, cerdas livres, cilíndricas.

Material examinado: Área da UFG, 01.VI.1969, J.A. Rizzo 4311 (UFG); borda da mata galeria da nascente que abastece o alojamento, 29.V.2009, A.M. Teles \& T.H.S. Sampaio 589 (UFG).

Ocorre nos estados de Goiás, Minas Gerais, Rio de Janeiro, São Paulo, Paraná e no Distrito Federal (Ritter et al. 2015). Diferencia-se das demais espécies do gênero ocorrentes na área de estudo por possuir lâmina foliar com base cordada e margem crenada. No PESD ocorre em cerrado rupestre e em borda de floresta galeria.

13. Mikania officinalis Mart., Reise Bras.1: 283.1823.

Fig. 4c

Subarbustos eretos, $80 \mathrm{~cm}$ alt. Folhas opostas, lâmina deltoide $0,5-3,5 \times 0,2-3,5 \mathrm{~cm}$, ápice agudo, base truncada, margem irregularmente serreada, glandulosa em ambas as faces. Pecíolo 1-4 mm compr. Capitulescência corimbiforme. Capítulos com pedúnculos $2-5 \mathrm{~mm}$ compr., pilosos e glandulares. Invólucro eximbricado, cilíndrico, $5 \times 2 \mathrm{~mm}$, brácteas involucrais 1-seriada, pilosas e glandulosas. Eixo da inflorescência plano, epaleáceo. Flores 4 por capítulo, corola alvacenta, lóbulos adaxialmente papilosos, abaxialmente glabros. Cipselas obcônicas, 5-costadas, 2,5 mm compr., papilosas. Pápus cerdoso, cerdas livres, cilíndricas.

Material examinado: Na cabeceira do Índio Grande, 17.XI.1994, J.A. Rizzo et al. 12024 (UFG); Reserva Biológica Prof. José Ângelo Rizzo, 17.XII.2011, G.H. Silva et al. 72 (UFG).

Ocorre no Brasil e Bolívia (King \& Robinson 1987). No Brasil ocorre nos estados da região Sul, além da Bahia, Goiás, Mato Grosso, Mato Grosso do Sul, Minas Gerais, São Paulo e Distrito Federal (Ritter et al. 2015). Distingue-se das demais do gênero ocorrentes no PESD por apresentar hábito de crescimento subarbustivo e ereto. Coletada no PESD em cerrado rupestre e em borda de floresta de galeria.

14. Mikania pohliana Sch.Bip. ex Baker, Fl. Bras. 6(2): 232. 1876.

Fig. 5d-e

Trepadeiras volúveis. Folhas opostas, lâmina ovada a lanceolada, 3-5 × 1,5-7 cm, ápice agudo a acuminado, base arredondada, margem inteira, pontuações glandulosa em ambas as faces. Pecíolo 0,5-1 cm compr. Capitulescência paniculiforme. Capítulos com pedúnculos $1 \mathrm{~mm}$ compr., pilosos. Invólucro eximbricado, campanulado $3 \times 2 \mathrm{~mm}$, brácteas involucrais 1-seriada, estrigosas. Eixo da inflorescência plano, epaleáceo. Flores 4 por capítulo, corola branca, lóbulos adaxialmente pilosos, abaxialmente glabros. Cipselas cilíndrica, 5-costadas, 0,5 mm compr., glabras. Pápus cerdoso, cerdas livres, cilíndricas.

Material examinado: Borda de mata galeria da nascente, 28.V.2011, A.M. Teles et al. 1328 (UFG).

Ocorre nos estados de Goiás, Mato Grosso do Sul, Minas Gerais, São Paulo e no Distrito Federal (Ritter et al. 2015). Distingue-se das demais espécies do gênero ocorrentes no PESD por possuir folhas com lâmina inteira e com pontuações glandulares em ambas as faces. Coletada no PESD em borda de floresta de galeria.

15. Mikania psilostachya DC., Prodr. 5: 190. 1836.

Fig. 4f-g

Trepadeiras volúveis. Folhas opostas, lâmina ovada a elíptica, $1-11 \times 0,4-5 \mathrm{~cm}$, ápice agudo, base aguda, margem serreada, adaxialmente escabra, abaxialmente pilosa e glandulosa. 
Pecíolo 5-12 mm compr. Capitulescência racemoespiciforme. Capítulos sésseis. Invólucro eximbricado, cilíndrico 3-5 × 1-2 $\mathrm{mm}$, brácteas involucrais 1-seriada bracteoladas, estrigosas e papilosas. Eixo da inflorescência plano, epaleáceo. Flores 4 por capítulo, corola branca, lóbulos adaxialmente papilosos, abaxialmente glabros. Cipselas fusiformes, 5-costadas, 3 mm compr., papilosas. Pápus cerdoso, cerdas livres, cilíndricas.

Material examinado: Área da UFG, 04.V.1969, J.A. Rizzo 4230 (UFG).

Ocorrente no Sul da América do Sul até a Bolívia (King \& Robinson 1987), amplamente distribuída no Brasil (Ritter et al. 2015). Se diferencia das demais espécies congenéricas ocorrentes na área de estudo pela capitulescência racemo-espiciforme.

16. Praxelis capillaris (DC.) Sch.Bip., Jahresber. Pollichia 22-24: 254. 1866.

Fig. 4h

Ervas eretas, $20-40 \mathrm{~cm}$ alt. Folhas verticiladas, lâmina filiforme, $1-2,5 \times 0,2-0,5 \mathrm{~cm}$, ápice agudo, base aguda, margem inteira, abaxialmente glandulosa, adaxialmente glabra, sésseis. Capitulescência paniculiforme. Capítulos com pedúnculos 10-35 mm compr., incanos. Invólucro imbricado, campanulado, 1-6 × 1-5 mm, brácteas involucrais 2-3-seriadas, glabras. Eixo da inflorescência cônico, epaleáceo. Flores 22-45 por capítulo, corola lilás, lóbulos com tricomas glandulares esparsos em ambas as faces. Cipselas prismáticas, 4-costada, 1 mm compr., costelas pilosas. Pápus cerdoso, cerdas livres, cilíndricas.

Material examinado: Da Reserva Biológica até os córregos Cafundó e Piçarrão, 12.V.1994, J.A. Rizzo et al. 11336 (UFG); Área da UFG, 04.V.1991, J.A. Rizzo 4186 (UFG); entre a trilhada rampa de decolagem de asa deltas e o alojamento, 25.IV.2009, A.M. Teles 566 (UFG); entre o alojamento e a rampa, 29.V.2009 A.M. Teles \& T.H.S. Sampaio 594 (UFG).

Ocorre nos estados de Goiás, Mato Grosso, Mato Grosso do Sul, Minas Gerais, Paraná e São Paulo (Esteves 2001). Caracterizada pelas folhas verticiladas com lâmina filiforme. No PESD a espécie ocorre em cerrado rupestre.

17. Praxelis diffusa (Rich.) Pruski, Brittonia 50(4): 475. 1998.

Fig. $4 \mathrm{i}$

Subarbustos eretos, $30-60 \mathrm{~cm}$ alt. Folhas opostas, lâmina ovada, $0,5-4 \times 0,3-2 \mathrm{~cm}$, ápice agudo, base obtusa, margem inteira a serreada, abaxialmente glandulosa, adaxialmente pilosa. Pecíolo 3-6 mm compr. Capitulescência corimbiforme. Capítulos com pedúnculos $0,5-3,8 \mathrm{~cm}$ compr., glabros. Invólucro imbricado, campanulado, 5-7 × 3-4 mm, brácteas involucrais 2-3-seriadas, glabras. Eixo da inflorescência cônico, epaleáceo. Flores 30-40 por capítulo, corola lilás, lóbulos glabros em ambas as faces. Cipselas, obovoides, $2 \mathrm{~mm}$ compr., ciliadas. Pápus cerdoso, cerdas livres, cilíndricas.

Material selecionado: Serra Dourada, cabeceira do rio Índio Grande, 15.IV.1994, J.A. Rizzo et al. 11292 (UFG); fazenda Quinta da Serra, 30.III.2012, A.M. Teles et al. 1414 (UFG).

Ocorre na Colômbia, Venezuela, Guiana, Peru e Brasil (King \& Robinson 1987). No Brasil é amplamente distribuída por praticamente todos os estados (Oliveira 2015c). Assemelha-se a $P$. grandiflora (DC.) Sch.Bip., porém difere pelas folhas pecioladas, pela capitulescência corimbiforme e pelo maior número de flores por capítulo (30-40) (vs. folhas sésseis, capitulescência paniculiforme e flores 47-70 por capítulo de $P$. grandiflora). No PESD foi coletada em borda de floresta semidecídua.

18. Praxelis grandiflora (DC.). Sch.Bip., Jahresber. Pollichia 22-24: 254. 1866.

Fig. $4 \mathrm{j}$

Subarbustos eretos, ca. $40 \mathrm{~cm}$ alt. Folhas opostas, lâmina oblonga, $0,6-4 \times 0,2-0,8 \mathrm{~cm}$, ápice agudo, base aguda à cuneada, margem serreada, hirsuta em ambas as faces, séssil. Capitulescência paniculiforme. Capítulos com pedúnculos 0,5-6,5 cm compr., hirsutos. Invólucro imbricado, 5-7 × 4-6 $\mathrm{mm}$, brácteas involucrais $2-3$-seriadas, pilosas. Eixo da inflorescência cônico, epaleáceo. Flores 47-70 por capítulo, corola lilás, lóbulos adaxialmente pilosos, abaxialmente glandulosos. Cipselas elipsoides, 4-costada, 3 mm compr., escabras. Pápus cerdoso, cerdas livres, cilíndricas.

Material examinado: Reserva Biológica Prof. Dr. José Ângelo Rizzo, entre a trilha da rampa de decolagem de asa deltas e o alojamento, 25.IV.2009, A.M. Teles et al. 565 (UFG); fazenda Quinta da Serra, 27.IV.2012, R.S. Guida 49 (UFG).

Ocorre nos estados da Bahia, Goiás, Mato Grosso, Mato Grosso do Sul, Minas Gerais, Paraná e São Paulo (Oliveira 2015c). Assemelha-se a P. diffusa pelo hábito de crescimento, porém difere com base nos comentários apresentados nesta última espécie. No PESD ocorre em cerrado rupestre.

19. Pseudobrickellia brasiliensis (Spreng.) R.M. King \& H. Rob., Phytologia 24: 75. $1972 . \quad$ Fig. 41

Subarbustos eretos, $1 \mathrm{~m}$ alt. Folhas alternas, espiraladas, lâmina linear, 2-4 ×0,1 cm, ápice agudo, base aguda, margem inteira, glabra em ambas as faces, séssil. Capitulescência corimbiforme. Capítulos com pedúnculos 0,5-4 mm compr., 
glabros. Invólucro imbricado, cilíndrico, 4-5 × 2-3 mm, brácteas involucrais 3-seriadas, glabras. Eixo da inflorescência plano, epaleáceo. Flores 4 por capítulo, corola creme-esverdeada, lóbulos adaxialmente papilosos, abaxialmente glabros. Cipselas cilíndricas, 6-costadas, $3 \mathrm{~mm}$ compr., pilosas. Pápus cerdoso, cerdas livres, cilíndricas. Material examinado: Reserva Biológica Prof. Dr. José Ângelo Rizzo, estrada para o Areial, 28.V.2011, G.H. Silva et al. 38 (UFG); próximo da pista de asa delta, 30.VII.2011, R.S. Guida et al. 24 (UFG); 30.VII.2011, R.S. Guida et al. 25 (UFG).

Ocorre nos estados da região Centro-Oeste, além do Pará, Rondônia, Tocantins, Bahia, Ceará, Maranhão, Piauí, Minas Gerais e São Paulo (Nakajima 2015). Distingue-se das demais espécies encontradas na área de estudo por possuir folhas espiradas congestas e com lâmina linear. No PESD foi coletada em cerrado rupestre.

\section{Stevia heptachaeta DC., Prodr. 5: 122. 1836.}

Fig. $4 \mathrm{~m}-\mathrm{n}$

Arbustos eretos, ca. $80 \mathrm{~cm}$ alt. Folhas opostas, lâmina estreito elíptica, $2-5,5 \times 0,3-0,8 \mathrm{~cm}$, ápice agudo, base aguda à cuneada, margem denteada, glandulosa em ambas as faces, séssil. Capitulescência paniculiforme. Capítulos com pedúnculos $0,5-2,5 \mathrm{~cm}$ compr., glandulosos. Invólucro eximbricado, cilíndrico, 4-5 x 2-4 mm, brácteas involucrais 1-seriada, glandulosas. Eixo da inflorescência convexo, epaleáceo. Flores 5 por capítulo, corola branca a lilás, lóbulos adaxialmente papilosos, abaxialmente glabros. Cipselas cilíndrica, 5-costadas, 4 mm compr., pilosas. Pápus aristado, aristas livres, planas na base.

Material selecionado: Área da UFG, 02.III.1969, J.A. Rizzo 3982 (UFG); 05.IV.1969, J.A. Rizzo 4049 (UFG); Reserva Biológica Prof. Dr. José Ângelo Rizzo, após o Areial, 27.III.2010, A.M. Teles et al. 784 (UFG); 28.IV.2012, R.S. Guida et al. 50 (UFG).

Ocorre nos estados da Bahia, Goiás, Minas Gerais e São Paulo (Nakajima 2015). Diferenciase das demais espécies ocorrentes no PESD por apresentar o número de brácteas involucrais igual o número de flores (5 / 5). No PESD ocorre em cerrado rupestre.

21. Stomatanthes dyctiophyllus (DC). H. Rob., Phytologia 20: 336. 1970.

Fig. 5a-b

Arbustos eretos, ca. $1 \mathrm{~m}$ alt. Folhas alternas na base, opostas próximo ao ápice, lâmina ovada, $1,5-4,5 \times 0,5-4 \mathrm{~cm}$, ápice obtuso, base aguda, margem serreada, serícia e glandulosa em ambas as faces, séssil. Capitulescência paniculiforme. Capítulos com pedúnculos 1-2 mm. Invólucro eximbricado, campanulado, 3-5 × 2-3 $\mathrm{mm}$, brácteas involucrais $2-$ seriadas, seríceas e glandulosas. Eixo da inflorescência plano, epaleáceo. Flores 6 6 por capítulo, corola creme esverdeada, lóbulos adaxialmente papilosos, abaxialmente glabros. Cipselas cilíndricas, 5-costadas, 1mm compr., pilosas. Pápus cerdoso, cerdas livres, cilíndricas.

Material examinado: Trilha de descida da serra após a nascente, 27.V.2011, A.M. Teles et al. 1286 (UFG); depois do Areial, 01.VII.2011, R.S. Guida et al. 23 (UFG); 01.VII.2011, R.S. Guida et al. 24 (UFG).

Ocorre nos estados de Goiás, Mato Grosso, Mato Grosso do Sul, Minas Gerais e São Paulo (Nakajima 2015). Distingue-se de S. loefgrenii por apresentar folhas alternas na base e opostas em direção ao ápice. No PESD ocorre em cerrado sentido restrito e cerrado rupestre.

22. Stomatanthes loefgrenii (B.L. Rob.) H. Rob., Phytologia 20: 337. $1970 . \quad$ Fig. 5c

Subarbustos eretos, $70 \mathrm{~cm}$ alt. Folhas alternas, lâmina ovada, $1,5-6 \times 0,5-2,5 \mathrm{~cm}$, ápice agudo, base aguda a cuneada, margem serreada, adaxialmente estrigosa, abaxialmente estrigosa e glandulosa, séssil. Capitulescência paniculiforme. Capítulos com pedúnculos 1-3 mm compr., estrigosos. Invólucro eximbricado, cilíndrico 4 $\times 2-3 \mathrm{~mm}$, brácteas involucrais 2-3-seriadas, pilosas, glandulosas. Eixo da inflorescência plano, epaleáceo. Flores 6 por capítulo, corola creme, lóbulos adaxialmente papilosos, abaxialmente glabros. Cipselas cilíndrica, 4-costadas, $2 \mathrm{~mm}$ compr., pilosas e glandulosas. Pápus cerdosos, cerdas livres, cilíndricas.

Material examinado: Da Reserva Biológica até os córregos Cafundó e Piçarrão, 14.IX.1994, J.A. Rizzo et al. 11803 (UFG); 18.X.1994, J.A. Rizzo et al. 11906 (UFG).

Reportada por Esteves (2001) e Nakajima (2015) apenas para o estado de São Paulo, e considerada como em criticamente em perigo de extinção por supostamente ser conhecida apenas pelo holótipo e pela área de ocupação bastante restrita e sob forte pressão antrópica (Nakajima et al. 2013). No entanto, Esteves (2001) citou um outro registro da espécie além do holótipo e neste trabalho é citada pela primeira vez para Goiás. Difere da outra espécie congenérica ocorrente na área de estudo por apresentar todas as folhas alternas. Foi coletada no PESD em cerrado sentido restrito e cerrado rupestre. 

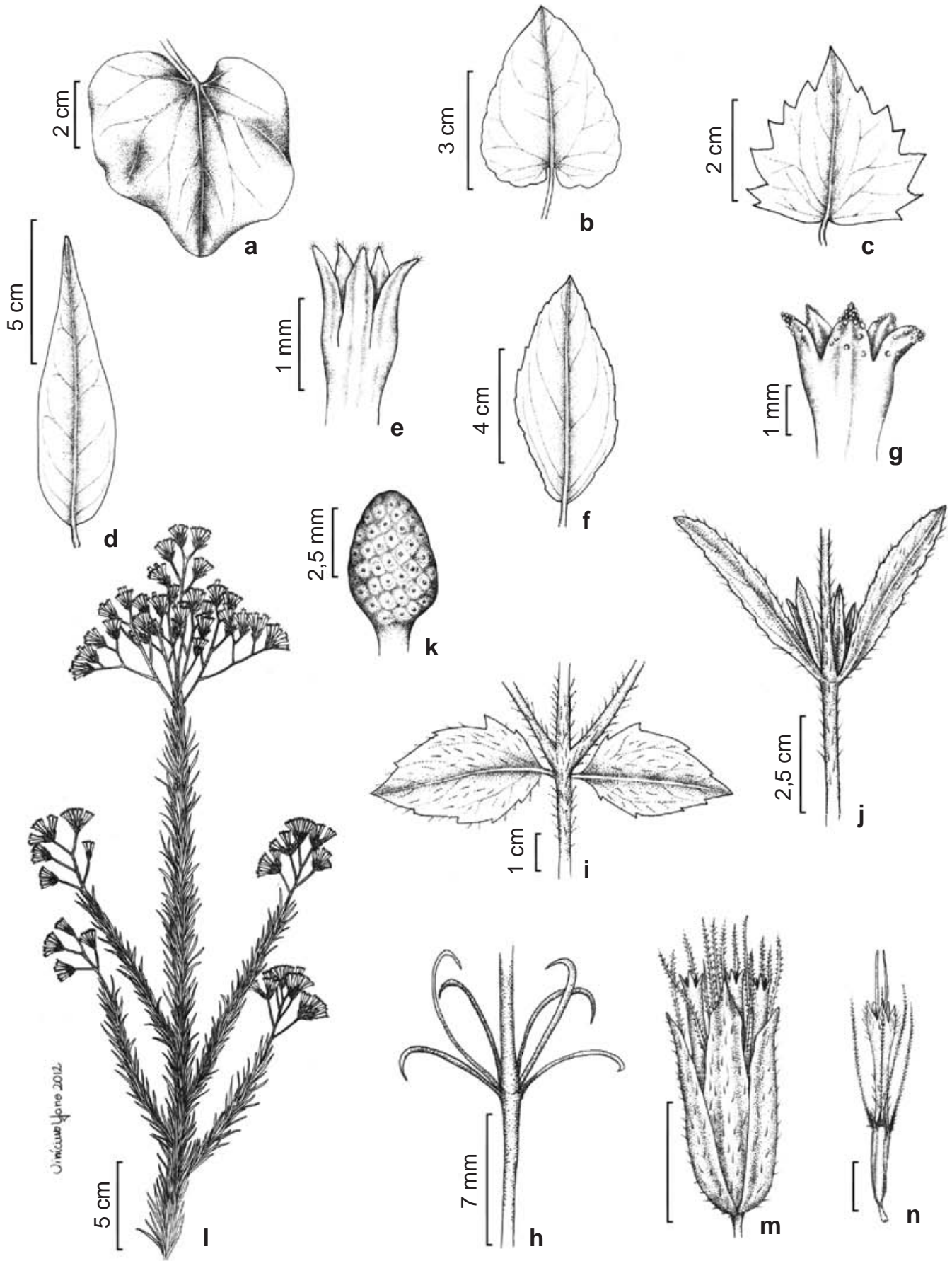

Figura 4 - a. Mikania cordifolia - a. folha (Silva 89). b. Mikania microcephala - b. folha (Teles \& Sampaio 589). c. Mikania officinalis - c. folha (Rizzo et al. 12024). d-e. Mikania pohliana - d. folha; e. lóbulos da corola (Teles et al. 1328). f-g. Mikania psilostachya - f. Folha; g. lóbulos da corola (Rizzo 4230). h. Praxelis capilaris - h. ramo com folhas (Teles 566) i. Praxelis diffusa - i. ramo com folhas (Klein et al. 2212); j-k. Praxelis grandiflora-j. ramo com folhas (Guida 49). k. eixo da inflorescência (Guida 49); 1. Pseudobrikelia brasiliensis - 1. ramo florido (Guida et al. 24). m-n. Stevia heptachaeta - m. capítulo; n. flor (Guida et al. 50). Figure 4 - a. Mikania cordifolia - a. leaf (Silva 89). b. Mikania microcephala - b. leaf(Teles \& Sampaio 589). c. Mikania officinalis - c. leaf (Rizzo et al. 12024). d-e. Mikania pohliana - d. leaf; e. corolla lobes (Teles et al. 1328). f-g. Mikania psilostachya - f. leaf; g. corolla lobes (Rizzo 4230). h. Praxelis capilaris - h. leafy branch (Teles 566) i. Praxelis diffusa - i. leafy branch (Klein et al. 2212); j-k. Praxelis grandiflora - j. leafy branch (Guida 49). k. inflorescence axis (Guida 49); 1. Pseudobrikelia brasiliensis - 1. flowering branch (Guida et al. 24). m-n. Stevia heptachaeta - m. capitula; $n$. floret (Guida et al. 50). 

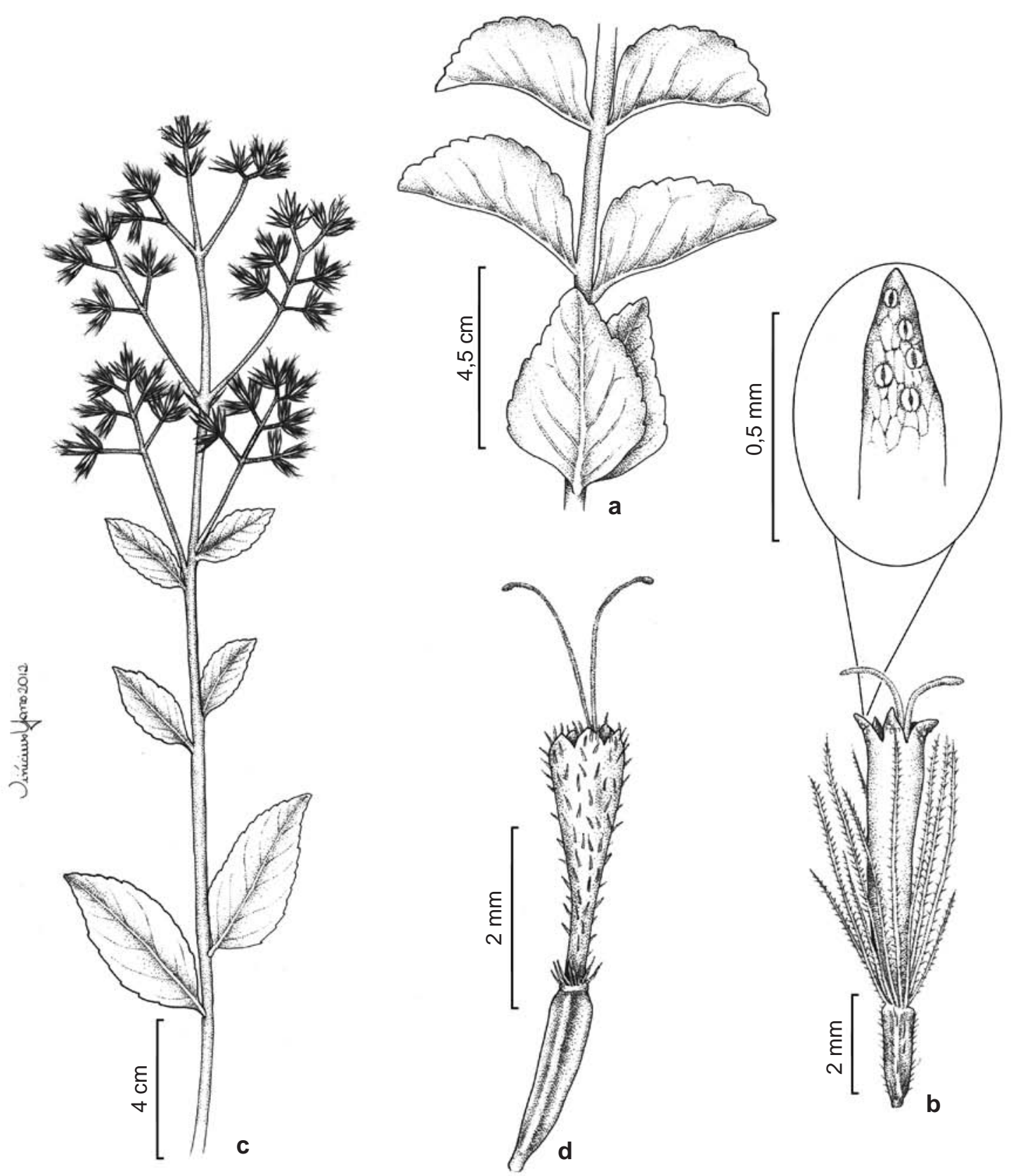

Figura 5 - a-b. Stomatanthes dyctiophyllus - a. filotaxia; b. flor evidenciando os estômatos nos lóbulos da corola (Guida et al. 23). c. Stomatanthes loefgrenii - ramo florido (Rizzo et al. 11803). d. Trichogonia cinerea - flor (Silva et al. 20). Figure 5 - a-b. Stomatanthes dyctiophyllus - a. branch; b. florets showing the stomata at corolla lobe (Guida et al. 23). c. Stomatanthes loefgrenii - flowering branch (Rizzo et al. 11803). d. Trichogonia cinerea - floret (Silva et al. 20).

23. Trichogonia cinerea (Gardner) R.M. King \& H. Rob., Phytologia 24: 178. 1972.

Fig. 5d

Subarbustos a arbustos eretos, $0,45-1,2 \mathrm{~m}$ alt. Folhas alternas, lamina lanceolada, $0,5-6,5 \times 0,1-1$ $\mathrm{cm}$, ápice agudo, base aguda a atenuada, margem serreada, pubescente e glandulosa em ambas faces. Pecíolos 1-5 mm compr., pubescentes. Capitulescência paniculiforme Capítulos com pedúnculos 5-30 $\mathrm{mm}$ compr., tomentosos. Invólucro eximbricado, campanulado 3-5 × 2-5 $\mathrm{mm}$, brácteas involucrais $2-3$-seriadas, tomentosas. Eixo da inflorescência convexo, epaleáceo. Flores 
50-70 por capítulo, corola lilás, completamente pilosa externamente. Cipselas cilíndricas, $2 \mathrm{~mm}$ compr., glandulosas. Pápus ausente.

Material selecionado: Divisa dos municípios de Mossâmedes ao sul, e Goiás ao norte, área da UFG, 02.III.1969, J.A. Rizzo 3994 (UFG); Reserva Biológica da UFG, 14.IV.1988, Ana \& Wesley 6532 (UFG); a 3 km do trevo de Mossâmedes para a cidade de Goiás, à esquerda da rodovia, $3^{\circ}$ transecto, 14.IV.1994, J.A. Rizzo 11201 (UFG); Reserva Biológica Prof. José Ângelo Rizzo entre a porteira e a guarita de vigilância, 24.IV.2009, A.M. Teles et al. 552 (UFG); próximo a porteira de entrada da Reserva, 30.IV.2011, G.H. Silva et al. 20 (UFG).

Ocorre nos estados da Bahia, Goiás, e no Distrito Federal (Roque et al. 2012). Caracterizase pelas flores com corola completamente pilosas externamente. Estes tricomas agrupam-se na base da corola dando uma falsa impressão de pápus, porém a espécie não apresenta pápus. No PESD a espécie ocorre em cerrado rupestre.

\section{Agradecimentos}

O primeiro autor agradece ao CNPq, a bolsa de iniciação científica (Edital PROTAX, processo 562290/2010-9). Agradecemos ainda à FAPEG, o auxílio financeiro ao Projeto (Edital PPP/FAPEG/ CNPq, processo 200910267000387).

\section{Referências}

Baker, J.G. 1876. Compositae II: Eupatoriaceae. In: Martius, C.F.P. von; Eichler, A.W. \& Urban, I. (eds.). Flora brasiliensis. Munchen, Wien, Leipzig. Vol. 6, pp. 181-374

Barbosa, M.A. 2008. O Ecoturismo e a sustentabilidade - Parque Estadual da Serra Dourada - GO (PESD). Dissertação de Mestrado. Pontifícia Universidade Católica de Goiás, Goiânia. 104p.

Barroso, G.M. 1950. Considerações sobre o gênero Eupatorium. Arquivos do Jardim Botânico do Rio de Janeiro 10: 13-116.

Barroso, G.M. 1958. Mikanieae do Brasil. Arquivos do Jardim Botânico do Rio de Janeiro 16: 239-333

Bentje, H. 2012. The Kew Plant Glossary - an illustrated dictionary of plant terms. Royal Botanic Gardens, Kew, Chicago. 164p.

Bremer, K. 1994. Asteraceae: cladistics and classification. Timber Press, Portland. 429p.

Bringel Jr., J.B.A. \& Cavalcanti, T.B. 2009. Heliantheae (Asteraceae) na Bacia do Rio Paranã (Goiás, Tocantins), Brasil. Rodriguésia 60: 551-580.

Carneiro, A.M. \& Irgang, B.E. 2005. Origem e distribuição geográfica das espécies ruderais da Vila de Santo Amaro, General. Câmara, Rio Grande do Sul. Iheringia, Série Botânica 60: 175188.
Esteves, R.L 2001. O gênero Eupatorium s.l. (Compositae - Asteraceae) no estado de São Paulo. Tese de Doutorado. Universidade Estadual de Campinas, Campinas. 314p.

Fernandes, A.C. 2014. Sistemática de Heterocondylus R.M. King \& H. Rob. (Eupatorieae, Asteraceae). Tese de Doutorado. Universidade Federal de Minas Gerais, Belo Horizonte. 122p.

Ferreira, S.C. 2010. Filogenia molecular da subtribo Gyptidinae R.M. King \& H. Rob. (Eupatorieae, Asteraceae) e revisão taxonômica do gênero Lasiolena R.M. King \& H. Rob. Tese de Doutorado. Universidade Estadual de Feira de Santana, Feira de Santana. 195p.

Ferreira, S.C. 2015a. Barrosoa. In: Lista de Espécies da Flora do Brasil. Jardim Botânico do Rio de Janeiro. Disponível em <http://floradobrasil.jbrj. gov.br/jabot/floradobrasil/FB16001>. Acesso em 19 abril 2015.

Ferreira, S.C. 2015b. Campuloclinium. In: Lista de Espécies da Flora do Brasil. Jardim Botânico do Rio de Janeiro. Disponível em $<$ http://floradobrasil. jbrj.gov.br/jabot/floradobrasil/FB16040>. Acesso em 19 abril 2015.

Filgueiras, T.S.; Nogueira, P.E.; Brochado, A.L. \& Guala, G.F. 1994. Caminhamento - um método expedito para levantamentos florísticos qualitativos. Caderno de Geociências 12: 39-43.

Funk, V.A., Susanna, A., Stuessy, T.F. \& Robinson, H. 2009. Classication of Compositae. In: Funk, V.A.; Susanna, A.; Stuessy, T.F. \& Bayer, R.J (eds.). Systematics, evolution, and biogeography of compositae. IAPT, Austria. Pp. 171-176.

Gonçalves, E.G. \& Lorenzi, H. 2011. Morfologia vegetal: organografia e dicionário ilustrado de morfologia das plantas vasculares. $2^{a}$ ed. Instituto Plantarum de Estudos da Flora, São Paulo. 512p.

Hattori, E.K.O. 2015. Ayapana. In: Lista de Espécies da Flora do Brasil. Jardim Botânico do Rio de Janeiro. Disponível em $<$ http://floradobrasil.jbrj. gov.br/jabot/floradobrasil/FB15981>. Acesso em 19 abril 2015.

Hattori, E.K.O. 2013. Filogenia molecular da subtribo Disynaphiinae (Eupatorieae: Asteraceae), tratamento taxonômico e sinopse de Symphyopappus, e anatomia floral do clado Grazielia - Symphyopappus. Tese de Doutorado. Universidade Federal de Minas Gerais, Belo Horizonte. 193p.

Hind, D.J.N. \& Miranda, E.B. 2008. Lista preliminar da Família Compositae na Região Nordeste do Brasil. Royal Botanic Gardens, Kew. 104p.

Hind, D.J.N. \& Robinson, H. 2007. Tribo Eupatorieae. In: Kadereit, J.M. \& Jeffrey, C. (eds.). The families and genera of vascular plants. Vol. 8. Springer, Berlin. Pp. 510-575.

Judd, W.S.; Campbell, C.S.; Kellogg, E.A.; Stevens, P.F. \& Donoghue, M.J. 2009. Sistemática vegetal. 
Um enfoque filogenético. $3^{\text {a }}$ ed. Artmed, Porto Alegre. 632p.

King, R.M. \& Robinson, H. 1987. The genera of the Eupatorieae (Asteraceae). Monographs in Systematic Botany. Missouri Botanical Garden 22: 1-581.

Matzenbacher, N.I. 1979. Estudo taxonômico do gênero Eupatorium L. (Compositae) no Rio Grande do Sul - Brasil. Dissertação de Mestrado. Universidade Federal do Rio Grande do Sul, Porto Alegre. 216p.

Moreira, G.L. \& Teles, A.M. 2014. A tribo Vernonieae Cass. (Asteraceae) na Serra Dourada, Goiás, Brasil. Iheringia, Série Botânica 69: 357-385.

Mori, S.A.; Berkov, A.; Gracie, C.A. \& Hecklau, E.F. 2011. Tropical plant collecting: from the field to the Internet. TECC, Florianópolis. 332p.

Nakajima, J.N. 2015. Ageratum. In: Lista de Espécies da Flora do Brasil. Jardim Botânico do Rio de Janeiro. Disponível em $<$ http://floradobrasil.jbrj. gov.br/jabot/floradobrasil/FB15932>. Acesso em 19 abril 2015.

Nakajima, J.N.; Loeuille, B.; Heiden, G.; Dematteis, M.; Hattori, E.K.O.; Magenta, M.A.G.; Ritter, M.R.; Mondin, C.A.; Roque, N.; Ferreira, S.C.; Borges, R.A.X.; Soares, P.N.; Almeida, G.; Schneider, A.; Sancho, G.; Saavedra, M.M.; Liro, R.M.; Pereira, A.C.M.; Moraes, M.D.; Silva, G.A.R.; Medeiros, J.D.; Lorencini, T.S.; Teles, A.M.; Monge, M.; Siniscalchi, C.M.; Souza-Buturi, F.O.; Bringel Jr., J.B. A.; Carneiro, C.R.; Pasini, E. \& Oliveira, C.T. 2015. Asteraceae. In: Lista de Espécies da Flora do Brasil. Jardim Botânico do Rio de Janeiro. Disponível em <http://floradobrasil.jbrj.gov.br/ jabot/floradobrasil/FB55>. Acesso em 19 abril 2015.

Nakajima, J.N. 2015. Pseudobrickellia. In: Lista de Espécies da Flora do Brasil. Jardim Botânico do Rio de Janeiro. Disponível em $<$ http://floradobrasil. jbrj.gov.br/jabot/floradobrasil/FB16272>. Acesso em 19 abril 2015.

Nakajima, J. 2015. Stomatanthes. In: Lista de Espécies da Flora do Brasil. Jardim Botânico do Rio de Janeiro. Disponível em $<$ http://floradobrasil.jbrj. gov.br/jabot/floradobrasil/FB117173>. Acesso em 24 abril 2015.

Nakajima, J.N.; Dematteis, M.; Loeuille, B.; Teles, A.M.; Heiden, G.; Schneider, A.; Ritter, M.; Oliveira, C.T.; Hattori, E.K.O.; Roque, N.; Ferreira, S.C.;
Magenta, M.; Bringel Jr., J.B. A.; Esteves, R.; Almeida, G.; Saavedra, M.M.; Monge, M.; Soares, P.N.; Sancho, G.; Mondin, C.A.; Fernandes, A.C.; Pereira, A.C.M.; Kutschenko, D.C.; Santos Filhos, L.A.F.; Prieto, P.V.; Borges, R.A.X.; Penedo, T.S.A.; Messina, T. Moraes, M.M.V.; Moraes, M.A. \& Coellho, M.A.N. 2013. Asteraceae - Angiosperma. In: Martinelli, G. \& Moraes, M.A. (orgs.). Livro Vermelho da Flora do Brasil. Instituto de Pesquisas de Jardim Botânico do Rio de Janeiro, Rio de Janeiro. Pp. 203-286.

Oliveira, C.T. 2015a. Chromolaena. In: Lista de Espécies da Flora do Brasil. Jardim Botânico do Rio de Janeiro. Disponível em $<$ http://floradobrasil.jbrj. gov.br/jabot/floradobrasil/FB16052>. Acesso em 19 abril 2015.

Oliveira, C.T. 2015b. Lomatozona. In: Lista de Espécies da Flora do Brasil. Jardim Botânico do Rio de Janeiro. Disponível em $<$ http://floradobrasil.jbrj. gov.br/jabot/floradobrasil/FB27240>. Acesso em 19 abril 2015.

Oliveira, C.T. 2015c. Praxelis. In: Lista de Espécies da Flora do Brasil. Jardim Botânico do Rio de Janeiro. Disponível em <http://floradobrasil.jbrj. gov.br/jabot/floradobrasil/FB16265>. Acesso em 19 abril 2015.

Robinson, H.; Schilling. E \& Panero, J.L. 2009. Eupatorieae. Classication of compositae. In: Funk, V.A; Suzana, A.; Stuessy, T.F. \& Bayer, R.J. (eds.). Systematics, evolution, and biogeography of compositae. IAPT, Austria. Pp. 731-744.

Roque, N.; Bautista, H.P. \& Mota, A.C. 2012. Taxonomic revision of Trichogonia (Eupatorieae, Asteraceae): a South American genus. Systematic Botany 37: 525-553.

Roque, N. \& Bautista, H.P. 2008. Asteraceae: caracterização e morfologia floral. EDUFBA Universidade Federal da Bahia, Salvador. 69p.

Ritter, M.R.; Liro, R.M.; Roque, N.; Nakajima, J.N; Souza-Buturi, F.O. \& Oliveira, C.T. 2015. Mikania. In: Lista de Espécies da Flora do Brasil. Jardim Botânico do Rio de Janeiro. Disponível em $<$ http://floradobrasil.jbrj.gov.br/jabot/floradobrasil/ FB5344>. Acesso em 19 abril 2015.

Ritter, M.R. \& Miotto, S.T.S. 2005. Taxonomia de Mikania Willd. (Asteraceae) no Rio Grande do Sul, Brasil. Hoehnea 32: 309-359. 


\section{Lista de exsicatas}

Ana \& Wesley.: 6532 (12.1); Teles, A.M. \& Sampaio, T.H.S.: 599 (5.2); 590 (5.3); 701 (5.4); 604 (6.1); 589 (7.1); 589 (7.2); 594 (8.1); Teles, A.M. et al.: 575 (1.1); 1231 (3.1); 1291 (4.1); 567 (5.1); 559 (5.2); 883 (5.2); 558 (5.4); 1255 (5.4) 884 (6.1); 1328 (7.4); 566 (8.1); 1414 (8.2); 565 (8.3); 784 (10.1); 1286 (11.1); 552 (12.1); Silva, G.H.: 89 (7.1); Silva, G.H. \& Teles, A.M.: 1 (5.3); 3 (4.1). Silva, G.H. et al.: 28 (5.4); 38 (9.1); 20 (12.1); 35 (5.2) Rizzo, J.A.: 4253 (6.1); 4262 (5.2); 4328 (6.1); 4311 (7.1); 4230 (7.5); 4186 (8.1); 3982 (10.1); 4049 (10.1); 3994 (12.1); 11201 (12.1); Rizzo, J.A. et al.: 11564 (2.1); 11287 (4.1); 11169 (5.4); 11437 (5.5); 11891 (5.5); 11305 (6.1); 1224 (7.3); 11336 (8.1); 11292 (8.2); 11803 (11.2); 11906 (11.2); Gibbs, P. et al.: 2753 (2.1); Guida, R.S. et al.: 3 (2.1); 27 (2.1); 10 (8.3); 17 (12.1); 26 (6.1); 44 (5.3); 47 (5.4); 48 (5.4) 49 (8.3); 50 (10.1); 25 (9.1); 23 (11.1); 24 (11.1). 
